\title{
Root, soil water and nitrogen dynamics in a catch crop - soil system in the Wageningen Rhizolab
}

\author{
A.M. VAN DAM* AND P.A. LEFFELAAR \\ Department of Theoretical Production Ecology, Wageningen Agricultural University. \\ P.O.Box 430, NL-6700 AK Wageningen, the Netherlands. \\ * Corresponding author (Current address: Bulb Research Centre, P.O.Box 85, NL-2160 AB \\ Lisse, The Netherlands. Fax: +252-417762; e-mail: anne.marie.van.dam@lbo.agro.nl)
}

Received 4 September 1997; accepted 21 July 1998

\begin{abstract}
Catch crops (winter rye and fodder radish) were grown on lysimeters with rhizotron facilities from August or September till March in two consecutive years, to study root growth and water and nitrogen dynamics under different regimes of irrigation and $\mathrm{N}$ supply. Catch crops took up 20 to $30 \mathrm{~g} \mathrm{~N} \mathrm{~m}^{-2}$, of which a considerable part (37-48\%) was present in dead leaves in March. Rooting depth increased by $2.6 \mathrm{~cm} \mathrm{day}^{-1}$ for both species at the start of the growing season.

Catch cropping reduced the $\mathrm{NO}_{3}^{-}-\mathrm{N}$ concentration in the soil considerably during the whole duration of the experiments, first in the top layers, than further down the soil profile. The reduction in total leached $\mathrm{N}$ was similar to the total crop $\mathrm{N}$ uptake. Nitrate- $\mathrm{N}$ concentrations in leached water were reduced by $49-85 \mathrm{mg} \mathrm{l}^{-1}$ (by 62 to $99 \%$ ), dependent on $\mathrm{N}$ availability and irrigation. Due to catch cropping the $\mathrm{NO}_{3}^{-}-\mathrm{N}$ concentration in the percolate decreased with increasing irrigation (or precipitation), whereas the amount of $\mathrm{N}$ leached increased with irrigation. Evapotranspiration from a catch cropped soil is close to the potential evapotranspiration under optimal growth conditions.
\end{abstract}

Keywords: winter rye, fodder radish, catch crops, evapotranspiration, nitrogen leaching, mineralization, nitrogen uptake, rhizotron, rooting depth.

\section{Introduction}

Catch crops are cultivated after the harvest of a summer crop to reduce losses of $\mathrm{N}$ by leaching during autumn and winter. They often effectively reduce the nitrate concentration in leaching soil water by absorbing up to $19 \mathrm{~g} \mathrm{~m}^{-2} \mathrm{~N}$ (Vos \& Van Der Putten, 1997). The $\mathrm{N}$ uptake by catch crops and the resulting reduction in $\mathrm{N}$ leaching from the soil widely vary with specific conditions in field experiments (Landman, 1990; Schröder et al., 1992). Analysis of the processes determining catch crop growth and $\mathrm{N}$ leaching may make it possible to relate observed variations to environmental conditions so that the effectiveness of catch crops in reduction of $\mathrm{N}$ leaching 
may be improved. The nitrogen uptake depends on the uptake capacity of the crop and the availability of $\mathrm{N}$ in the rooted soil. Rooting depth and root density are important characteristics and determine how much nitrogen can be taken up (Van Noordwijk, 1982). Catch crop species differ in root density and in the rate at which rooting depth increases (Thorup-Kristensen, 1993), and consequently, the rate at which $\mathrm{N}$ in various soil layers can be taken up by the crop.

The rate of $\mathrm{N}$ leaching depends on the percolation rate of soil water and its $\mathrm{N}$ concentration. Both will vary from one year and location to another. Both percolation rate and $\mathrm{N}$ concentration in the soil solution are reduced by catch crops. Little is known about transpiration by catch crops and the subsequent reduction in percolation rate. Simulated transpiration by a catch crop under Swedish conditions is 30 to $50 \mathrm{~mm}$ water from mid August until the start of April (Lewan, 1993).

The aim of this paper is to quantify the effects of precipitation, catch cropping and $\mathrm{N}$ fertilizer rates on soil water and $\mathrm{N}$ dynamics and catch crop biomass, $\mathrm{N}$ uptake and root growth.

\section{Materials and methods}

The Wageningen Rhizolab (Van De Geijn et al., 1994) is a facility to monitor both soil $\mathrm{N}$ transport and root length in a soil profile throughout the growing season of crops; it combines the features of a lysimeter with those of a rhizotron. Time courses of root development, soil solution nitrogen concentration, water content and temperature in the soil profile can be followed. Soil $\mathrm{N}$ transport and relevant catch crop growth processes, such as root growth and $\mathrm{N}$ uptake were studied in the Rhizolab, and the results were used to interpret results of field studies better, and to estimate how much $\mathrm{N}$ will leach with and without cultivation of a specific catch crop, in various conditions. Two experiments were done in the Rhizolab. Experiment 1 in 1993-1994 with fodder radish and Experiment 2 in 1994-1995 with winter rye.

\section{Experiment 1}

In Experiment 1, from 1 September 1993 until 14 March 1994, fodder radish was grown on two $1.25 * 1.25 \mathrm{~m}$ Rhizolab compartments at two irrigation regimes. Two other compartments were kept fallow and received the same irrigation. The low irrigation rate (Ilow) was equivalent to $1 \mathrm{~mm} \mathrm{day}^{-1}$ until 2 November, and to $2 \mathrm{~mm} \mathrm{day}^{-1}$ thereafter, comparable to a rather dry autumn and normal Dutch winter. The high rate (Ihigh) was equivalent to $3 \mathrm{~mm}$ day $^{-1}$, comparable to an extremely wet winter. Irrigation was supplied twice a week. Below, treatments are indicated with CIlow, CIhigh, FIlow and FIhigh, where C stands for 'cropped' and F for 'fallow'.

The Rhizolab compartments filled from 0 to $100 \mathrm{~cm}$ below ground level with a sandy soil with an organic matter content of $41 \mathrm{mg} \mathrm{g}^{-1}$ dry matter and a $\mathrm{pH}-\mathrm{H}_{2} \mathrm{O}$ of 6 , and packed to a dry bulk density of $1.35 \mathrm{~g} \mathrm{~cm}^{-3}$. From 100 to $170 \mathrm{~cm}$ below ground level, a river sand without organic matter was used with $\mathrm{pH}-\mathrm{H}_{2} \mathrm{O}$ of 4.5 , packed to a bulk density of $1.54 \mathrm{~g} \mathrm{~cm}^{-3}$. The soil profiles were unfertilized, and drained at 170 
$\mathrm{cm}$ below ground level. After Experiment 1 the sandy soil was taken out of the Rhizolab compartments and stored until August 1994 when it was used in Experiment 2.

Fodder radish was sown on 1 September 1993 at $12.5 \mathrm{~cm}$ row distance. After emergence the plants were thinned in the rows to 1 per $4 \mathrm{~cm}$. This is a bit higher than to the normal seeding density of 1.2 to $2.0 \mathrm{~g} \mathrm{~m}^{-2}$. Fodder radish was also sown around the compartments to minimize border effects, e.g., incidence of light directly on the side of the canopy.

Crop management was aimed at optimal growth conditions: sowing depth and distances between the seeds were standardized. Spots with low plant densities were filled with plants transplanted from outside, assuring a good and homogeneous crop establishment. Water shortage, sometimes delaying emergence in field experiments, was absent. The radish crop was protected against frost by covering it with transparant plastic, below which the air was heated to $4 \pm 2{ }^{\circ} \mathrm{C}$ and ventilated. This happened during frost periods from 19 November to 6 December 1993 and from 11 to 25 February 1994. The border plants had frozen to death in the first frost period. Therefore, on 10 December 1993 the crop was surrounded by a vertically installed shade gauze transmitting about $50 \%$ of the light, with the same height as the crop. The crop was harvested on 15 March 1994, about the normal incorporation time in practice.

Because of the limited number of Rhizolab compartments available it was impossible to replicate the treatments. Everything possible was done to avoid differences from one compartment to another, except for the imposed treatments: the compartments were filled with the same soil in the same way and were placed next to each other, so that environmental conditions were similar. Because of these precautions it is plausible that clear differences between compartments are due to the treatments and not to compartment effects.

To determine the nitrogen mineralization rate, sandy soil was stored in plastic bags with the open end rolled up (about $200 \mathrm{~g}$ soil per bag with a gravimetric water content of 20\%). The samples were buried at $15 \mathrm{~cm}$ below ground level next to the Rhizolab compartments, so that they were subject to the same temperatures as the soil in the compartments. At two to four week intervals during the experiment, five bags were removed for determination of mineral $\mathrm{N}$ fractions. The mineral $\mathrm{N}$ present in the bags after incubation, minus that present at the start of the experiment, was assumed to be mineralized from organic matter. It increased in time, and in Experiment 2 , then decreased, presumably due to denitrification. The maximum value of mineralised $\mathrm{N}$ in the course of time was taken as the total $\mathrm{N}$ mineralized during the experiment.

\section{Experiment 2}

Winter rye was grown in four Rhizolab compartments from 24 August 1994 until 17 March 1995. The compartments were filled with the same soil in the same way as in Experiment 1. All compartments received $3.07 \mathrm{~g} \mathrm{~m}^{-2} \mathrm{P}$ and $10.0 \mathrm{~g} \mathrm{~m}^{-2} \mathrm{~K}$, respectively, in the top $10 \mathrm{~cm}$. There were four $\mathrm{N}$ fertilization rates: (1) zero $\mathrm{N}$ (N0), (2) $7 \mathrm{~g}$ 
$\mathrm{m}^{-2}$ at sowing in the upper $10 \mathrm{~cm}$ of the soil profile (N7s), (3) the same plus an extra application of $7 \mathrm{~g} \mathrm{~m}^{-2} \mathrm{~N}$, supplied with the irrigation water, equally divided over three applications at 26, 36 and 47 days after sowing (N14), and (4) $7 \mathrm{~g} \mathrm{~m}^{-2} \mathrm{~N}$ placed at 40-50 cm depth in the soil (N7d). The deep placement was meant to test the effect of $\mathrm{N}$ that has 'leached' already to a certain depth before the catch crop starts to grow. $\mathrm{N} 14$ is meant to be amply supplied with $\mathrm{N}$ during the whole experiment. The irrigation rate was equivalent to $3 \mathrm{~mm}$ day $^{-1}$, to study the performance of the crop at a high percolation rate. Soil properties and drainage conditions were the same as in Experiment 1.

Winter rye was sown on 24 August 1994 at $12.5 \mathrm{~cm}$ row distance in the compartments. Only seeds of 2.5 to $3 \mathrm{~mm}$ in diameter were used, to obtain a homogeneous crop. Rye was also sown around the compartments. The distance between seeds in the row was $1.5 \mathrm{~cm}$, corresponding to the normal seeding density of $18 \mathrm{~g} \mathrm{~m}^{-2}$. On 30 August all rows contained 70 plants or more. There were no replications. The same precautions to avoid compartment effects were taken as in Experiment 1. Net $\mathrm{N}$ mineralization was determined from the increase in mineral $\mathrm{N}$ in soil buried in plastic bags near the Rhizolab compartments, similar to Experiment 1.

\section{Measurements}

Rhizolab measuring equipment was installed in the soil profiles according to Van De Geijn et al. (1994) unless changes are mentioned below.

Root number was determined regularly as described by Smit et al. (1994), by recording the roots on video tape in horizontally installed glass tubes (minirhizotrons) and counting the number of roots at regular positions in the profile. Root length was measured in auger samples taken at $10 \mathrm{~cm}$ depth intervals at 3 occasions during the growing season (October, November, March).

Soil moisture content was determined hourly by capacitive moisture sensors, and daily averages were calculated for selected days (matching $\mathrm{N}$ measurements) and used in further calculations. In soil solution and in drainage water, $\mathrm{NO}_{3}^{-}-\mathrm{N}$ and $\mathrm{NH}_{4}^{+}-\mathrm{N}$ concentrations were determined according to Walinga et al. (1989). The soil solution was sampled with under-pressurized ceramic cups and porous tubes. The amount of drainage water was recorded and it was sampled weekly for determination of $\mathrm{NO}_{3}^{-}-\mathrm{N}$ and $\mathrm{NH}_{4}^{+}-\mathrm{N}$ concentrations. For Experiment 1, the measurements of $\mathrm{NO}_{3}^{-}-\mathrm{N}$ concentrations in the drainage water failed. To estimate leached $\mathrm{N}$, the concentrations measured once every 14 days at $150 \mathrm{~cm}$ depth were used. The concentrations in the weeks between these measurements were obtained by linear interpolation.

For determination of mineral $\mathrm{N}$ balances, $\mathrm{NO}_{3}^{-}-\mathrm{N}$ and $\mathrm{NH}_{4}^{+}-\mathrm{N}$ were determined in auger samples of the soil collected at two occasions during the growing season (at sowing and at harvest).

Capacitive sensors, thermocouples, ceramic cups and porous tubes were installed in duplicate at $5,10,15,20,30,40,60,85,115$ and $150 \mathrm{~cm}$ below ground level in Experiment 1. In Experiment 2, the depths were adapted to have a better monitoring of the fate of fertilizer $\mathrm{N}$ applied from 40 to $50 \mathrm{~cm}$ below ground level. They were 
installed in duplicate at 5, 15, 30, 45, 55, 70, 90, 115 and $150 \mathrm{~cm}$ below ground level.

Soil from the bags incubated to determine mineralization was dried at $40{ }^{\circ} \mathrm{C}$ and extracted with $0.01 \mathrm{M} \mathrm{CaCl}_{2}$ and subsequently concentrations of $\mathrm{NO}_{3}^{-}-\mathrm{N}, \mathrm{NH}_{4}^{+}-\mathrm{N}$ and total soluble $\mathrm{N}$ were determined (Walinga et al., 1989). Mineralization data were converted to $\mathrm{g} \mathrm{m}^{-2}$ in the Rhizolab compartments assuming a uniform bulk density and a uniform mineralization rate in the layer $0-100 \mathrm{~cm}$ below ground level.

At the end of the experiment, the crops were harvested. For fodder radish (Experiment 1) living and dead leaves, stems and pen roots were distinguished. Winter rye (Experiment 2) was separated in living leaf blades and sheaths, dead leaves and stubbles. Root weights were determined in auger samples. Total N concentrations were determined in all plant parts (Novozamsky et al., 1974, 1983) except for radish fine roots, in which the same $\mathrm{N}$ concentration as in pen roots was assumed.

\section{Calculations}

Radiation use efficiency was calculated by assuming half of radiation between emergence and canopy closure to be intercepted, and all radiation after canopy closure. For estimating amounts of nitrogen and water in the profile the point measurements were assumed representative for a layer around the point of measurement (e.g. the measurement at $5 \mathrm{~cm}$ for $0-10 \mathrm{~cm}$ depth, at $90 \mathrm{~cm}$ for $80-100 \mathrm{~cm}$ depth). Evapotranspiration during a period was calculated according to Equation 1 with all terms in $\mathrm{mm}$ :

evapotranspiration $=$ irrigation - change in soil water content - leaching

For comparison, the potential evapotranspiration (Penman, 1948) was calculated. Data were used from the weather station at Wageningen, at $2 \mathrm{~km}$ from the experimental site.

\section{Results}

\section{Soil water balance}

The soil water balance was evidently affected by the treatments in Experiment 1 (Figure 1a-d), but not in Experiment 2 (Figure 1e-h): the differences in N supply did not affect transpiration by the rye crop (Figure $1 \mathrm{~h}$ ). The water storage in the profile $(0-170 \mathrm{~cm}$ depth) increased to an equilibrium level that increased with irrigation rate (Figure 1b). In CIlow the soil water was temporarily depleted, but the equilibrium level was the same as in FIlow after the irrigation rate had been increased from 1 to $2 \mathrm{~mm} \mathrm{day}^{-1}$. At the end of the experiments (cumulative) evapotranspiration was on average $40 \pm 11 \mathrm{~mm}$ (average and standard deviation over the specified group of compartments) for the fallow compartments, $204 \pm 15 \mathrm{~mm}$ in radish (Figure 1d) and 

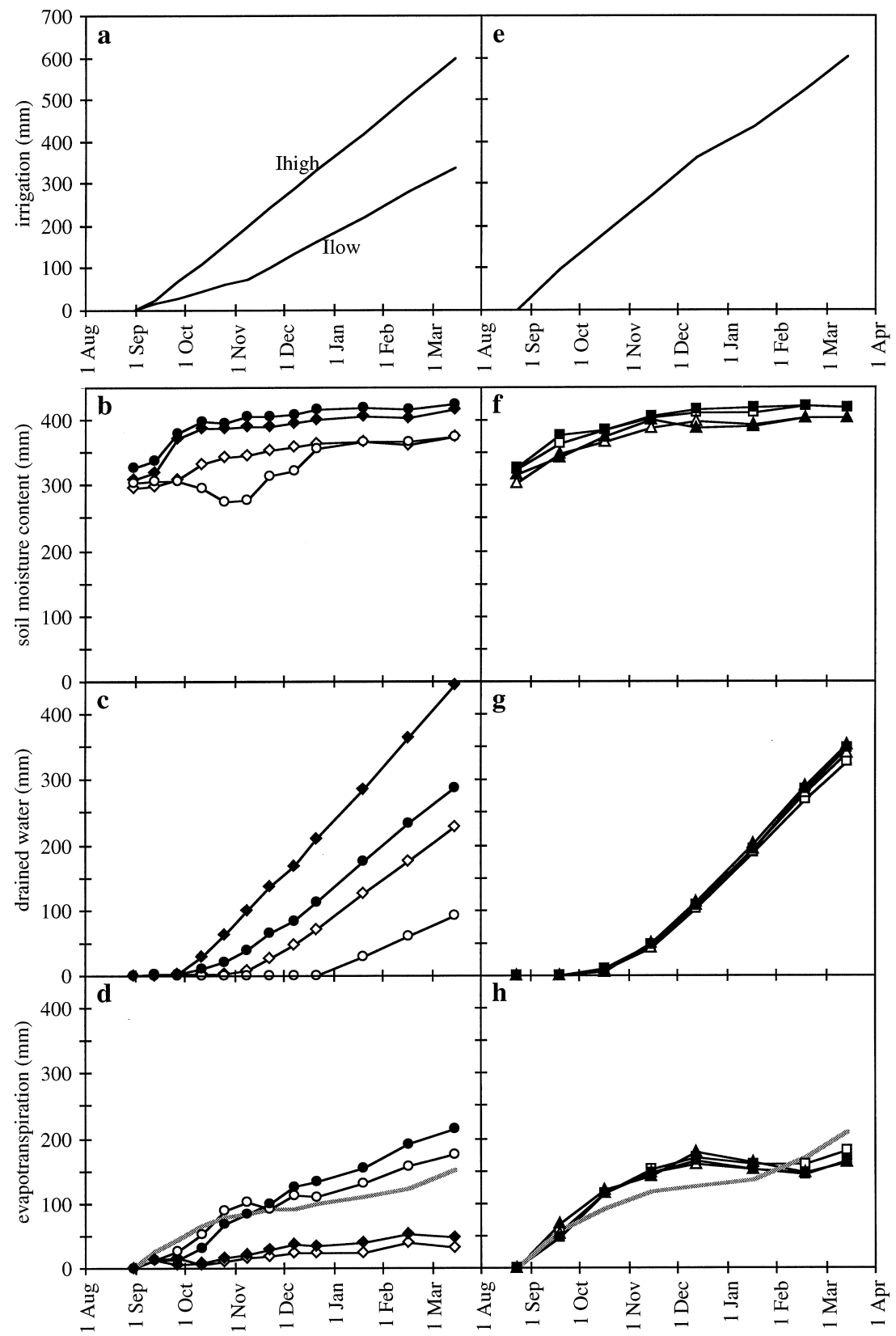

Figure 1. Soil water dynamics in Experiments 1 (fallow/fodder radish; a-d) and 2 (winter rye; e-h). a and e: Cumulative irrigation. b and f: Total soil water in the profile. $\mathrm{c}$ and $\mathrm{g}$ : Cumulative drained water. $\mathrm{d}$ and h: Cumulative evapotranspiration and potential evapotranspiration. Symbols: b-d: $\prec-=$ Fllow,

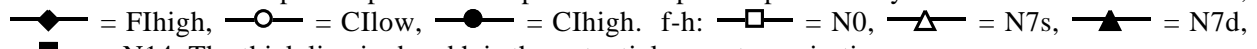
$\longrightarrow-\mathrm{N} 14$. The thick line in $\mathrm{d}$ and $\mathrm{h}$ is the potential evapotranspiration. 
$168 \pm 9 \mathrm{~mm}$ in rye (Figure $1 \mathrm{~h}$ ). Rye had a high evapotranspiration rate until the end of November and did not transpire much until february, when it increased again. Radish continued to transpire throughout the winter. Radish reduced total leaching by $155 \pm 2 \mathrm{~mm}$, compared to fallow (Figure 1c). The difference in leaching between Ihigh and Ilow was $215 \pm 2 \mathrm{~mm}$, not as large as the difference in irrigation, $259 \mathrm{~mm}$ (Figure 1a). This is also reflected by a higher water storage at the high irrigation rate (Figure 1b). The evapotranspiration in the cropped treatments was sometimes higher than the potential evapotranspiration that was calculated from the weather data.

\section{Soil $N$ balance}

The $\mathrm{N}$ balances of Experiments 1 and 2 (Table 1) differ considerably in both their input and output terms. Firstly, the mineral $\mathrm{N}$ content at the start of the experiment is higher in Experiment 2, in N0, than in any treatment of Experiment 1. This is probably because a crop had grown on the soil just before Experiment 1, whereas it had been stored for 5 months before the start of Experiment 2. During that time, Nmin had increased by mineralization, from the low final Nmin concentrations of Experiment 1 . The rigorous mixing of the soil before filling the Rhizolab compartments will also have increased Nmin by stimulating mineralization. The balances of the profiles are mostly not zero, and differ from one treatment to another. Positive balances, (2-18\% of $\mathrm{N}$ present at the start, applied or mineralized) mean that not all $\mathrm{N}$ is recovered at the end of the growth period in the profile, the leachate and the crop. This may be due to inaccuracies in measurements, or to unquantified processes: denitrification was not measured, but may amount up to $20 \%$ of the available ni-

Table 1. Mineral $\mathrm{N}$ balances $\left(\mathrm{g} \mathrm{m}^{-2}\right)$ of soil profiles in Experiments 1 and 2. See text for explanation of treatments.

\begin{tabular}{lrrrr}
\hline Experiment 1 & Fllow & Flhigh & Cllow & CIhigh \\
a. Profile start (8 September 1993) & 12 & 12 & 12 & 12 \\
b. Mineralisation & 21 & 21 & 21 & 21 \\
c. Leaching & 18 & 22 & 0 & 1 \\
d. Crop uptake radish & 0 & 0 & 20 & 20 \\
e. Profile end (16 March 1994) & 11 & 11 & 9 & 6 \\
Balance (a+b-c-d-e) & 5 & 0 & 5 & 6 \\
\hline Experiment 2 & N0 & N7s & N7d & N14 \\
a. Profile start (24 Aug 1994) & 19 & 20 & 18 & 18 \\
b. Mineralisation & 23 & 23 & 23 & 23 \\
c. Fertilisation & 0 & 7 & 7 & 14 \\
d. Leaching & 9 & 12 & 17 & 18 \\
e. Crop uptake rye & 27 & 25 & 27 & 3 \\
f. Profile end (13 Mar 1995) & 2 & 3 & 3 & 6 \\
Balance (a+b+c-d-e-f) & 4 & 9 & 1 & \\
\hline
\end{tabular}


trate under winter field conditions (Richter \& Richter, 1991). Moreover, some N may be present in unrecovered decomposing crop material. In Experiment 2, the unrecovered Nmin was higher in N7s and N14, that were fertilized at the top of the profile, than in the other treatments. Denitrification may have been higher in N7s and $\mathrm{N} 14$, due to the extra $\mathrm{N}$ available from fertilization, compared to N0. In N7d, N leaching was earlier and more intensive, so less $\mathrm{N}$ could be denitrified than in $\mathrm{N} 7 \mathrm{~s}$ and N14. Apparently this was not counteracted by a possibly lower oxygen concentration in the subsoil than at the top of the profile.

Crop $\mathrm{N}$ uptake was not affected by the treatments (Table 1). Fodder radish depleted the profile in March, compared to fallow. It reduced leaching effectively. At the very high $\mathrm{N}$ availability in Experiment 2, rye could not prevent $\mathrm{N}$ leaching completely, despite its high $\mathrm{N}$ uptake.

\section{Crop biomass and $N$ accumulation}

Both biomass and $\mathrm{N}$ in the crop were higher in rye (Experiment 2) than in radish (Experiment 1) (Figure 2). Experiment 2 also had the highest $\mathrm{N}$ supply in the soil, both in fertilized and unfertilized treatments (Table 1). Also, sowing was 8 days earlier in Experiment 2, allowing the rye crop to grow longer at relatively high light intensities in September and October (Table 2). Radiation use efficiency was on average $0.70 \mathrm{~g} \mathrm{MJ}^{-1}$ global radiation in radish and $1.0 \mathrm{~g} \mathrm{MJ}^{-1}$ in rye. Moreover, November was warmer in 1994 (rye) than in 1993 (radish) (Table 2). Total biomass was not affected by the treatments; in rye N7s and N7d had a somewhat lower biomass than $\mathrm{N} 0$ and $\mathrm{N} 14$, but for $\mathrm{N}$ only $\mathrm{N} 7 \mathrm{~s}$ is lower. There was no consistent effect of increase in $\mathrm{N}$ supply on total biomass. This can be explained by the high $\mathrm{N}$ availability in the soil without fertilization (Table 1). However, root biomass decreased

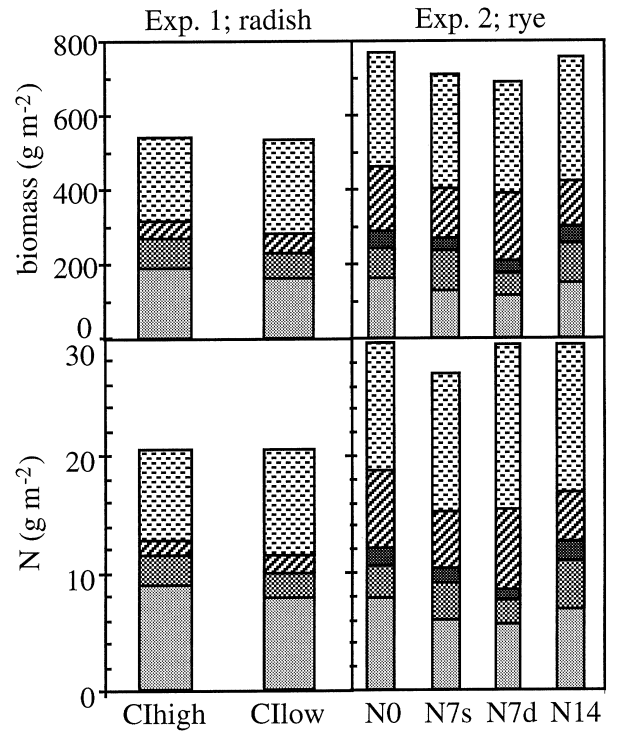

Figure 2. Crop biomass and $\mathrm{N}$ contents at the end of the experiments. $\square$ = green leaves, $\square=$ stems (incl. rye sheaths), $\square=$ stubble, $\square=$ roots, $\square$ = dead leaves. 
Table 2. Monthly average weather data during Experiments 1 and 2, compared to long term averages for the Netherlands (Bor et al., 1994). Temperature in ${ }^{\circ} \mathrm{C}$; Global radiation in $10^{7} \mathrm{~J} \mathrm{~m}^{2} \mathrm{month}^{-1}$.

\begin{tabular}{lcccccccc}
\hline Temperature & Aug & Sep & Oct & Nov & Dec & Jan & Feb & Mar \\
Experiment 1 & 14.7 & 12.8 & 9.1 & 2.4 & 4.6 & 4.8 & 1.2 & 7.0 \\
Experiment 2 & 17.4 & 13.8 & 9.3 & 9.7 & 4.9 & 3.3 & 6.4 & 5.2 \\
Long term av. & 16.7 & 14.2 & 10.7 & 6.1 & 3.3 & 2.2 & 2.5 & 4.9 \\
\hline Radiation & & & & & & & & \\
Experiment 1 & 40.7 & 26.9 & 19.1 & 9.3 & 4.0 & 7.1 & 14.7 & 23.7 \\
Experiment 2 & 48.9 & 23.9 & 21.1 & 8.6 & 6.3 & 8.1 & 11.3 & 30.9 \\
Long term av. & 47.4 & 31.8 & 19.2 & 9.0 & 5.5 & 7.1 & 13.8 & 26.0 \\
\hline
\end{tabular}

with N supply in rye (N0 - N7d - N7s - N14). The shoot root ratio (dead leaves excluded) was higher in radish than in rye, confirming results from other experiments (Van Dam \& Hüner, unpublished results; Vos \& Van der Putten, 1997). 40 to 50\% of biomass and 37 to $48 \%$ of $\mathrm{N}$ was present in dead leaves, indicating a considerable biomass turnover.

$\mathrm{N}$ concentrations were $47 \mathrm{mg} \mathrm{g}^{-1}$ in green leaves, $35 \mathrm{mg} \mathrm{g}^{-1}$ in dead leaves, $32 \mathrm{mg}$ $\mathrm{g}^{-1}$ in stems and $27 \mathrm{mg} \mathrm{g}^{-1}$ in pen roots of radish. In rye these concentrations were 47 $\mathrm{mg} \mathrm{g}^{-1}$ in green leaves, $39 \mathrm{mg} \mathrm{g}^{-1}$ in dead leaves, $35 \mathrm{mg} \mathrm{g}^{-1}$ in sheaths and stems and $24 \mathrm{mg} \mathrm{g}^{-1}$ in roots.

\section{Root length}

The rooting depth reached $100 \mathrm{~cm}$ on 6 and 13 October in radish at low and high irrigation respectively, and on 29 September in rye in all treatments (Figure 3a, d). On average the rooting depth increased $2.6 \mathrm{~cm} \mathrm{day}^{-1}$ in radish and rye.

The numbers of roots counted on the glass tubes are presented in Figure $3 \mathrm{~b}$ and e for a selection of measurement dates. After 12 October in rye and 13 October in radish, the changes in root numbers were small (data not shown). Therefore, for later dates the root length densities (RLD) in the auger samples are presented (Figure 3c, f). Both on the glass tubes and in the auger samples rye had more roots than radish. The shape of the root profile was similar for both species; Root density was high in the top $10 \mathrm{~cm}$ and much lower and slightly decreasing with depth in the rest of the profile. After mid October, roots accumulated at $100 \mathrm{~cm}$ depth, on the interface of the topsoil and the subsoil, into which the roots did not grow. This effect was more pronounced in radish than in rye. In radish, RLD was lower in the top $50 \mathrm{~cm}$ in Ihigh than in Ilow, but below $60 \mathrm{~cm}$ depth the root length density was higher in Ihigh than in Ilow; the roots in Ihigh showed a greater tendency to explore deeper layers as compared to Ilow. 
A.M. VAN DAM AND P.A. LEFFELAAR

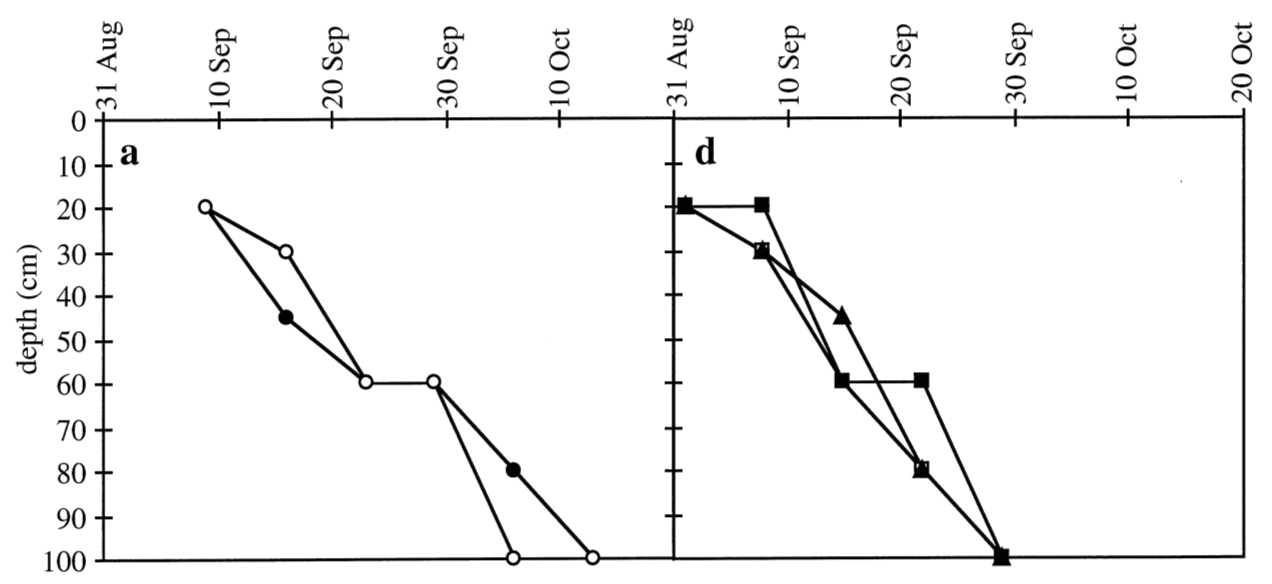

number of roots $\mathrm{cm}^{-2}$

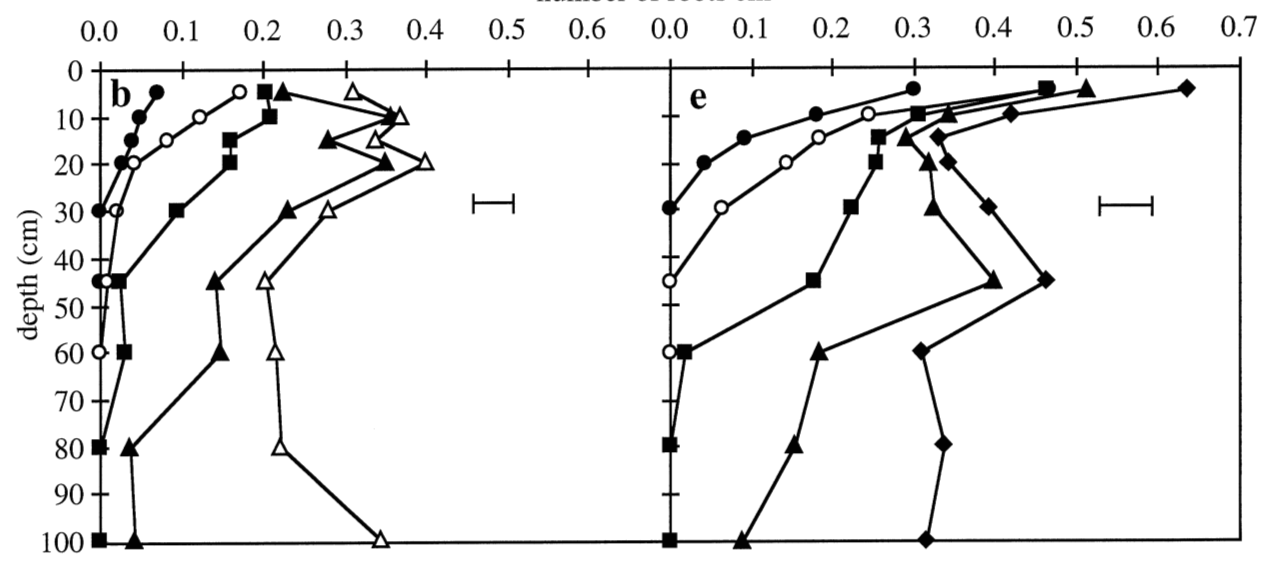

root length density $\left(\mathrm{cm} \mathrm{cm}^{-3}\right)$

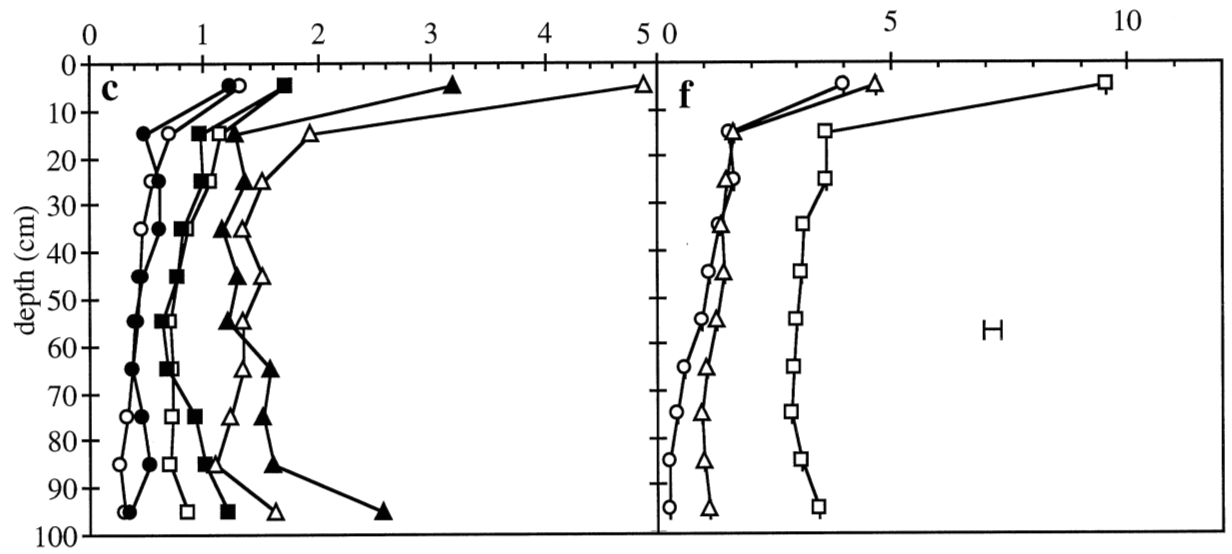




\section{Nitrogen in soil and drainage water.}

Leaching started later in Ilow than in Ihigh in Experiment 1, and later in the cropped than in the fallow compartments (Figure 4). The amount of $\mathrm{N}$ leached increased with irrigation (Experiment 1) and with N supply (Experiment 2: N0 - N7s - N7d - N14) (Table 1). In N7d the increase in N leaching compared to N0 $\left(8 \mathrm{~g} \mathrm{~m}^{-2}\right)$ was slightly larger than the nitrogen application. In N7s and N14 only a part of the applied N leached. Nitrate concentrations in drainage water were higher in FIlow (78 $\mathrm{mg} \mathrm{l}^{-1}$ on average) than in FIhigh (50 $\mathrm{mg} \mathrm{l}^{-1}$ on average). The radish catch crop reduced the average $\mathrm{NO}_{3}^{-}-\mathrm{N}$ concentration in drainage water to 1 and $5 \mathrm{mg} \mathrm{l}^{-1}$ in CIlow and CIhigh, respectively. The difference in $\mathrm{N}$ leaching between FIlow and FIhigh is relatively small: the amount of $\mathrm{N}$ leached in FIlow was $82 \%$ of that in FIhigh (Table 1) although the amount of leached water in FIlow was only $51 \%$ of that in FIhigh. In CIlow, leaching started only after the irrigation had been increased from 1 to $2 \mathrm{~mm}$ day $^{-1}$. In rye the $\mathrm{NO}_{3}^{-}-\mathrm{N}$ concentration in the leachate increased with $\mathrm{N}$ supply, from $26 \mathrm{mg} \mathrm{l}^{-1}$ in N0 to $51 \mathrm{mg} \mathrm{l}^{-1}$ in N14.

The effect of growing a catch crop on the amount of $\mathrm{NO}_{3}^{-}-\mathrm{N}$ in soil and drainage water was evident: the maximum difference in the $\mathrm{NO}_{3}^{-}-\mathrm{N}$ content of profiles between fallow and radish-cropped treatments is $22 \mathrm{~g} \mathrm{~N} \mathrm{~m}^{-2}$, quite similar to the $\mathrm{N}$ present in the radish crop at harvest $\left(20 \mathrm{~g} \mathrm{~m}^{-2}\right.$, Table 1$)$. On 14 March the nitrate content of the profile in the fallow treatment was still higher than in the cropped treatment on 14 March (Figure 4), suggesting that fodder radish continued to take up $\mathrm{N}$ until the end of the experiment. The Nmin content of the radish-cropped profiles in March, based on $\mathrm{N}$ concentrations in the auger samples (Table 1), were however higher than those of $\mathrm{NO}_{3}^{-}-\mathrm{N}$ based on the soil solution measurements (Figure 4). $\mathrm{NH}_{4}^{+}-\mathrm{N}$ concentrations were negligible. Therefore, it seems that in some cases not all mineral $\mathrm{N}$ can be measured from soil solution samples extracted with suction cups and porous tubes. This method may lead to underestimation of Nmin.

In Experiment 2 (Figure 5) the time course of the nitrate content of the profile had the same pattern in all treatments: $\mathrm{N}$ present at the start was depleted, first in the upper soil layers, than also in the deeper ones. On 17 October no nitrate was left in the soil down to $50 \mathrm{~cm}$ depth in N7s and to $60 \mathrm{~cm}$ depth in N0 and N7d. Thereafter a net increase in $\mathrm{NO}_{3}^{-}$occurred in that layer until 16 February, after which the nitrate content of the soil profile decreased, suggesting an increase in rye uptake activity towards spring; leaching rate was constant during that period. In N7s and N14 the $\mathrm{NO}_{3}^{-}$

Figure 3. Root profiles during Experiments 1 (a-c) and 2 (d-f). In b, e and f, root parameters are averaged over the treatments (bars are average standard deviations). a and d: Rooted depth. b and e: Numbers of roots in the profile at several moments from sowing to mid October. c and f: Root length density at three moments during the growing season. (Note: $\mathrm{X}$-axes in $\mathrm{c}$ and $\mathrm{f}$ have different scales).

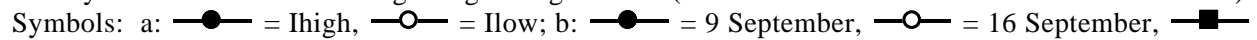
$=23$ September, $\longrightarrow-6$ October, $\triangle \Delta-13$ October; c: Ilow: $-\mathbf{-}-\mathbf{-}=15$ October $93, \square-\square=$ 17 November 93, $\square-15$ March 94, Ihigh: $\longrightarrow-15$ October 93, $\longrightarrow-=17$ November 93,

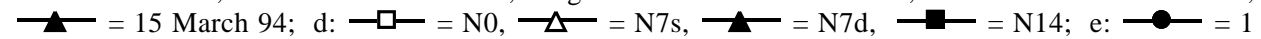
September, $\longrightarrow \mathbf{-}=8$ September, $\longrightarrow-=15$ September, $\longrightarrow-=29$ September, $\square-12$ October; f: $\longrightarrow$ - $=12$ October 94, $\square-10$ November 93, $\square-\square=14$ March 94. 


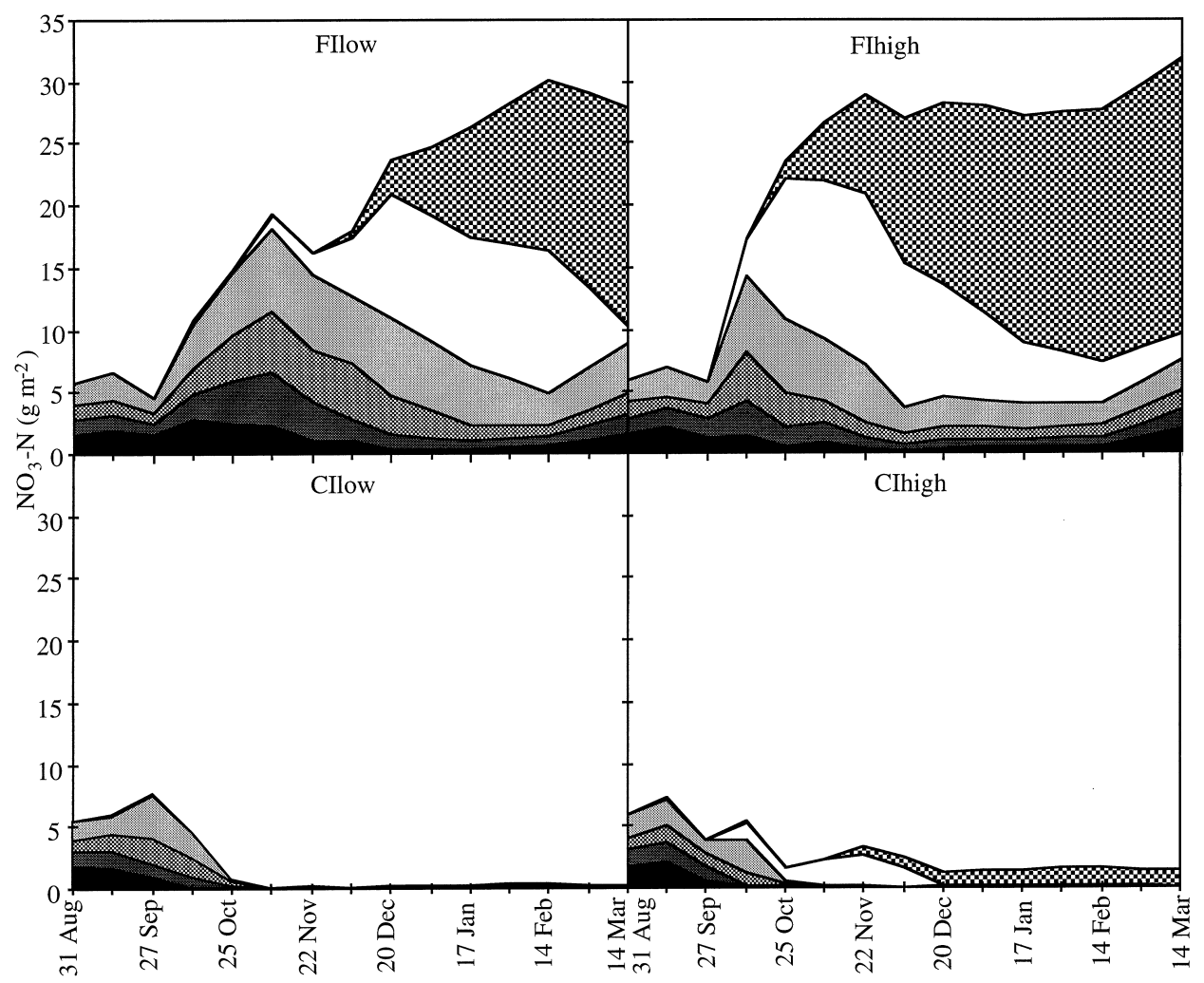

Figure 4. $\mathrm{NO}_{3}^{-}-\mathrm{N}$ contents in layers of soil profiles and in drainage water during Experiment 1 . Areas represent contents $\left(\mathrm{g} \mathrm{m}^{-2}\right)$ measured in soil solution in different layers (in $\mathrm{cm}$ depth) and leached water. Symbols: $\square=0-30 \mathrm{~cm}$ depth, $\square=30-50 \mathrm{~cm}, \square=50-70 \mathrm{~cm}, \square=70-100, \square=100-170 \mathrm{~cm}, \square=$ leached.

content of the soil increased at the start of the experiment. In N14 this will have been due to the split application of N, but the difference in behaviour between N7s on one hand and $\mathrm{N} 0$ and $\mathrm{N} 7 \mathrm{~d}$ on the other cannot be explained by this. $\mathrm{NH}_{4}^{+}-\mathrm{N}$ concentrations in soil were low during the whole of the experiments (data not shown).

\section{Discussion}

\section{$N$ accumulation}

Crop management was directed at optimal growth conditions and resulted in a high $\mathrm{N}$ uptake in both experiments. Treatments had no effect on total biomass production or $\mathrm{N}$ accumulation, although the partitioning to root increased when supply of water or $\mathrm{N}$ decreased. The small magnitude of the treatment effects indicate that growth 


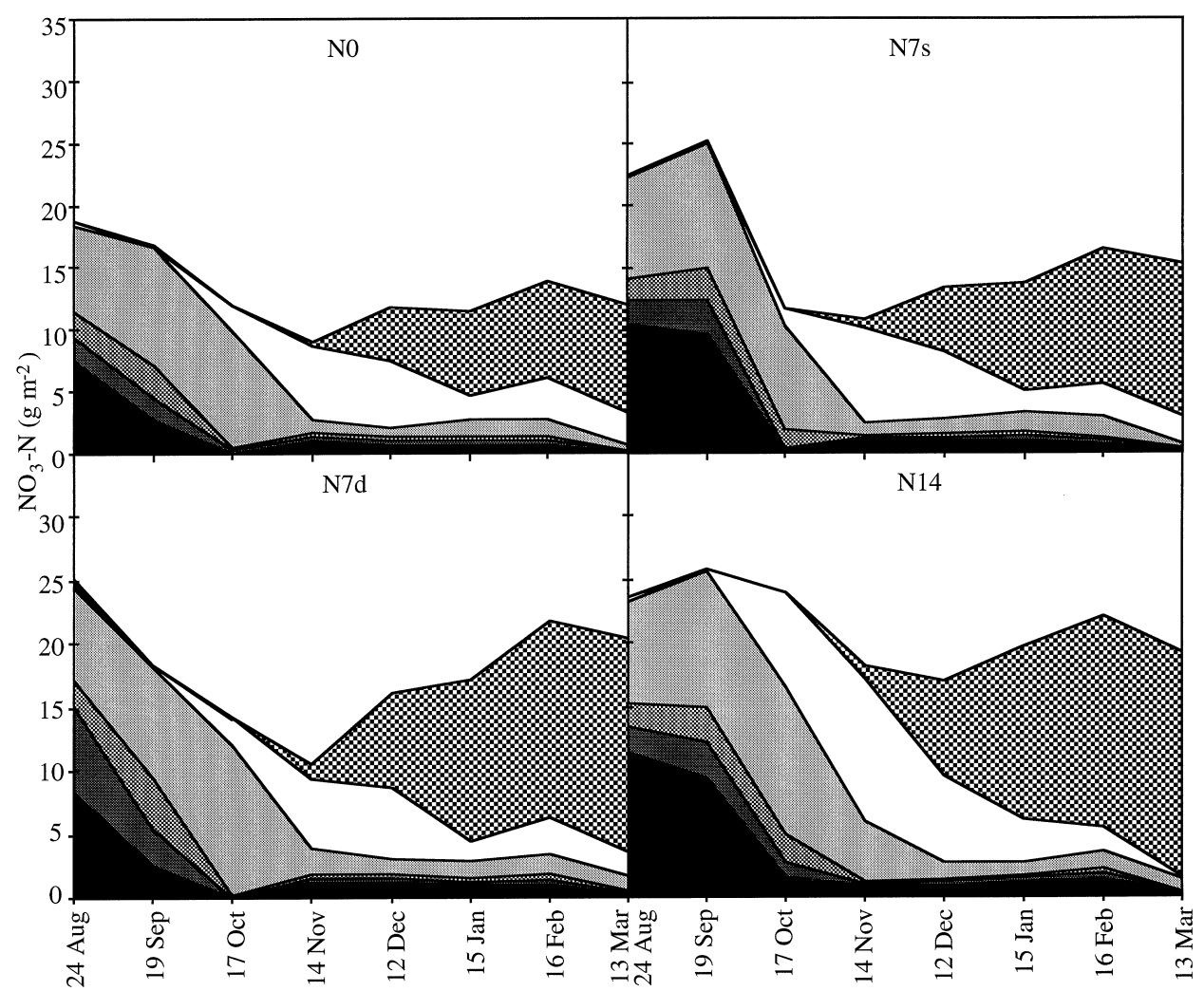

Figure 5. $\mathrm{NO}_{3}^{-}-\mathrm{N}$ contents in layers of soil profiles and in drainage water during Experiment 2. Areas represent contents measured in soil solution in different layers (in $\mathrm{cm}$ depth) and leached water. Symbols: $\square=0-40 \mathrm{~cm}$ depth, $\square=40-50 \mathrm{~cm}, \square=50-60 \mathrm{~cm}, \square=60-100, \square=100-170 \mathrm{~cm}, \square=$ leached.

conditions were already close to optimal at the lowest levels of $\mathrm{N}$ and water supply. Despite the precautions to minimize edge effects of the compartments, growth may have been slightly enhanced by light falling on the side of the canopy. The high transpiration, sometimes higher than the potential evapotranspiration, is an indication of this. Nevertheless the radiation use efficiency was rather low when compared to other studies (e.g. $1.25 \mathrm{~g} \mathrm{MJ}^{-1}$ global radiation for cereals, Gallagher \& Biscoe, 1978; $1.19 \mathrm{~g} \mathrm{MJ}^{-1}$ for catch crops, Vos \& Van Der Putten, 1997). Weather conditions were not exceptional for the Netherlands (Table 2).

The shoot to root ratio was higher in radish than in rye, as is also found in other experiments (Vos \& Van der Putten, 1997; Lainé et al., 1993). This implies that radish invested relatively less biomass in roots without any evidence that the amount of roots limited nutrient uptake. This may be so because radish compensated for the smaller investment in root biomass by its higher specific root length $(667 \pm 82 \mathrm{~cm}$ $\mathrm{g}^{-1}$ in radish and $254 \pm 53 \mathrm{~cm} \mathrm{~g}^{-1}$ in rye). Yet, when evaluated by root length instead 
of biomass, rye still had a more extensive root system than radish (Figure $3 \mathrm{c}$ and $\mathrm{f}$ ). At the start of the growing season, before the canopy is closed, this may enhance growth: more biomass can be invested in shoots, and thus more light can be intercepted. Rye has, however, a higher specific leaf area (Vos \& Van der Putten, 1997), so that it would need less leaf mass for the same light interception.

The nitrogen content of the crop were high compared to summer crops of the same biomass (Greenwood et al., 1990) but in the same range as those reported for amply fertilized catch crops by Vos and Van Der Putten (1997). This may be due to the different growth conditions as compared to summer crops, and the resulting difference in development stage: both rye and radish consisted mainly of vegetative material at harvest. Therefore in modelling the growth of a rye catch crop, the crop $\mathrm{N}$ concentration is related to temperature sum rather than biomass (Van Dam et al., 1996). In most catch crop studies, less biomass was formed, and less nitrogen accumulated (e.g. Landman, 1990; Sörensen, 1992). Vos and Van der Putten (1997), however, found biomass and nitrogen accumulation in catch crops in the same range as reported here. Nitrogen concentrations in dead leaves were also high compared to other studies, e.g. in grassland (Whitehead, 1995). Redistribution of $\mathrm{N}$ from senescing tissue is less important in a catch crop in winter than in a summer crop: in winter the growth rate of the crop may be so low that not all $\mathrm{N}$ from the dying tissue is needed for new biomass.

The amount of dead leaves is mostly lower in field experiments than found here (Figure 2; Vos \& Van der Putten, 1997). This may be due to the lush growth of the crops here, which promoted senescence by shading. Also, in the field decomposition of dead leaves may occur, where the $\mathrm{N}$ content of a catch crop may show a net decrease of as much as $6 \mathrm{~g} \mathrm{~m}^{-2} \mathrm{~N}$ from November to March (Vos \& Van der Putten, 1997). In Experiments 1 and 2, the dead leaves accumulated on top of the gravel layer, above the irrigation system, so that they were rather dry and less susceptible to decomposition than dead leaves on a moist soil surface in the field. The decomposition in the field experiments may lead to underestimation of total growth and $\mathrm{N}$ accumulation of catch crops.

Deep rooting assured the possibility to take up all $\mathrm{N}$ in the $0-100 \mathrm{~cm}$ layer, so that $\mathrm{N}$ transported downward could yet be absorbed. In October in both experiments the rooting density was much higher than required for unrestricted $\mathrm{N}$ uptake (Van Noordwijk, 1982). The average rate of increase in rooting depth of $2.6 \mathrm{~cm}^{-1 a y^{-1}}$ is comparable to the average rate in fodder radish in a field soil, $2.3 \mathrm{~cm} \mathrm{day}^{-1}$, calculated from data of Thorup-Kristensen (1993). In the field, increase in rooting depth in rye is much slower than in radish (Thorup-Kristensen, 1993), a difference that did not occur in the Rhizolab. Here, the soil profile was homogeneous from 0 to $100 \mathrm{~cm}$ depth and initially Nmin was high in this whole layer. This may have caused rye roots to grow deeper and faster in the Rhizolab than in a field soil, in which nutrients and organic matter are mostly concentrated in the top $40 \mathrm{~cm}$ of the profile. Later in the season, radish had a stronger tendency than rye to accumulate roots at the bottom of the topsoil (at $100 \mathrm{~cm}$ below ground level, Figure 3e and f). This may be caused by a relatively greater tendency in radish than in rye to grow deep into the soil. However, it may also be influenced by smaller amounts of $\mathrm{N}$ available to radish than 
to rye: in Experiment 1 there was no nitrate left to radish in the top $100 \mathrm{~cm}$ at the beginning of November. This is supported by a stronger accumulation of roots at 100 $\mathrm{cm}$ below ground level in CIhigh, in which $\mathrm{N}$ leached faster, than in CIlow (Figure $3 \mathrm{c})$. For rye, $\mathrm{N}$ was available in the top $100 \mathrm{~cm}$ during the whole experiment.

The results show that nitrogen accumulation by a catch crop is potentially very high. From field experiments lower values have been reported (Landman, 1990; Schröder et al., 1992). Differences may be due to a slower or less complete crop establishment, freezing of non-winterhardy crops, shallower rooting and lower nitrogen availability trough autumn and winter. Exploring these factors may yield clues to improvement of catch crop efficacy.

\section{Leaching}

When reduction of nitrogen leaching is considered, two factors are important. Firstly, the concentration of nitrate in the leaching water should preferably be lower than the Maximum Allowable Concentration (MAC) of $11.3 \mathrm{mg} \mathrm{N} \mathrm{1}^{-1}$, according to the EC Nitrate Directive (Tunney, 1992). Secondly, the amount of $N$ that is leached from the plant-soil system is important, because $\mathrm{N}$ losses cost much energy, if they are replaced by fertilizer (i.e. $38.6 \mathrm{MJ} \mathrm{kg}^{-1} \mathrm{~N}$, Evers \& Pothoven, 1995).

The average nitrate concentrations in the leachate were reduced to values below the MAC by radish in Experiment 1. Concentrations were reduced by 73 and $49 \mathrm{mg}$ $\mathrm{N}^{-1}$ in Ilow and Ihigh, respectively. No fallow treatments were included in Experiment 2 , but if all $\mathrm{N}$ taken up by rye had leached, average concentrations in the leachate would have been $85 \pm 4 \mathrm{mg} \mathrm{N}^{-1}$ higher than they were now. Catch crops are effective in reducing the $\mathrm{N}$ concentration in leaching water, and the reduction is larger at low than at high irrigation (and hence percolation). For reducing the nitrate concentration in the leachate it is desirable that a catch crop transpires little water. Figure $1 \mathrm{~d}$ and $\mathrm{h}$ suggest that evapotranspiration is not dependent on species, but on the potential evapotranspiration rate.

The amount of nitrogen that leached increased with irrigation (Experiment 1, Figure 4) and with $\mathrm{N}$ supply (Experiment 2, Figure 5). Thus, the effect of irrigation (or precipitation) on the amount of leached $\mathrm{N}$ is different from the effect on the concentration in the leachate, which decreased with increase in irrigation. Deep placement of fertilizer in N7d increased leaching, compared to N7s; in N7d fertilizer N was less available to other processes, like uptake and denitrification, because it leached earlier. However, $\mathrm{N}$ uptake was about the same in N7s and N7d. In N7s more $\mathrm{N}$ may have been denitrified than in $\mathrm{N} 7 \mathrm{~d}$, resulting in more unrecovered nitrogen in the balance (Table 1). Compared to field experiments (e.g. Wyland et al., 1996; Schröder et al., 1996), leached $\mathrm{N}$ was high, because $\mathrm{N}$ supply was also high. The high $\mathrm{N}$ supply by mineralization presumably resulted from soil mixing at the start of the experiments.

\section{$N$ availability in the soil profile}

Ideally, catch cropping will reduce $\mathrm{N}$ in soil during autumn and winter, so that less $\mathrm{N}$ 
leaches. Moreover, it will increase $\mathrm{N}$ availability in the succeeding spring and summer for the next crop, by mineralization of $\mathrm{N}$ from the catch crop. As proved in this study (Figures 4 and 5) and other ones (Elers \& Hartmann, 1987; Breland, 1996), catch cropping indeed reduces $\mathrm{N}$ in the profile in autumn and winter. However, in March, $\mathrm{N}$ in soil is still lower in the cropped profiles compared to the fallow treatments. In Experiment 2, the soil $\mathrm{N}$ content is even decreased from February to March, presumably by increased uptake activity of rye at increasing temperatures in this period. At that moment, $\mathrm{N}$ availability is decreased by the catch crop, so that extra fertilizer might be required to reach the same $\mathrm{N}$ availability as in the fallow soil. In the field, decomposition of dead leaf material may increase soil $\mathrm{N}$, especially when a catch crop is killed by frost. Therefore, the optimal moment for harvesting a catch crop or incorporating it in the soil would be after the main leaching period, but, in case of a winter-hardy catch crop species, before the start of renewed growth at the end of winter. When the catch crop is ploughed into the soil, the time needed for mineralization of catch crop $\mathrm{N}$ and the time course of the $\mathrm{N}$ demand of the succeeding crop should also be taken into account for optimizing $\mathrm{N}$ availability after a catch crop.

We conclude that under Rhizolab conditions a considerable percentage (up to $48 \%$ ) of catch crop $\mathrm{N}$ was present in dead material at the end of the catch crop growth period, which is more than in field experiments. Dead material may decompose faster in the field (due to wetter conditions) so that catch crop $\mathrm{N}$ accumulation in field experiments may be underestimated. A rye catch crop sown at the end of august can potentially take up $28 \mathrm{~g} \mathrm{~m}^{-2} \mathrm{~N}$. Potentially, rooting depth increases by 2.6 $\mathrm{cm} \mathrm{day}^{-1}$ for both species at the start of the growing season.

Catch cropping greatly reduced the $\mathrm{NO}_{3}^{-}-\mathrm{N}$ concentration in soil, first in the top layers, then further down the soil profile. The reduction in $\mathrm{N}$ leaching is similar to crop $\mathrm{N}$ uptake. Nitrate- $\mathrm{N}$ concentrations in leached water can be reduced by values up to $49-85 \mathrm{mg} \mathrm{l}^{-1}$, depending on $\mathrm{N}$ availability and irrigation. The reduction in $\mathrm{NO}_{3}^{-}-\mathrm{N}$ concentration in the leachate by catch cropping decreases with irrigation (or precipitation), whereas the leached amount of $\mathrm{N}$ increases with irrigation. Evapotranspiration from a catch cropped soil is close to the potential (Penman) evapotranspiration.

\section{Acknowledgements}

We thank J. Groenwold and J. Hessels of the DLO Institute for Agrobiology and Soil Fertility (AB-DLO) and G. Versteeg, J.E. Hofman, L. van Schöll, L. Hüner, H. Heij and T.K. van Eck for technical assistance and two anonymous referees, R. Rabbinge and $\mathrm{J}$. Vos for their comments on the text. 


\section{References}

Breland, T.A., 1996. Green manuring with clover and ryegrass catch crops undersown in small grains: effects on soil mineral nitrogen in field and laboratory experiments. Acta Agriculturae Scandinavica, Sect. B, Soil and Plant Sci. 46: 178-185.

Bor, N., J. Harbers, G. Hiemstra, R. Mauritz, G. Peters \& L. Wartena, 1994. Weerkunde voor de agrarische sector. Stamtechniek, Houten, $248 \mathrm{p}$.

Elers, B. \& H.D. Hartmann, 1987. Welche Zwischenfrüchte binden das meiste Nitrat?. DLG-Mitteilungen 10: 526-529.

Evers, M.A.A. \& R. Pothoven, 1995. Handboek Meststoffen. Nutrienten Management Instituut en Misset Uitgeverij, Wageningen, $480 \mathrm{p}$.

Gallagher, J.N. \& P.V.Biscoe, 1978. Radiation absorption, growth and yield of cereals. Journal of Agricultural Science, Cambridge 91: 47-60.

Greenwood, D.J., G. Lemaire, G. Gosse, P. Cruz, A. Draycott \& J.J. Neeteson, 1990 . DEcline in the percentage $\mathrm{N}$ in $\mathrm{C} 3$ and $\mathrm{C} 4$ crops with increasing plant mass. Annals of Botany 66:425-436.

Lainé, P., A. Ourry, J. Macduff, J. Boucaud \& J. Salette 1993. Kinetic parameters of nitrate uptake by different catch crop species: effects of low temperature or previous nitrate starvation. Physiologia plantarum 88: 85-92.

Landman, A., 1990. Stikstofconservering door groenbemesters. In: Jaarboek 1989/1990 - afgesloten onderzoek, Publicatie 54, PAGV, Lelystad, p. 268-272.

Lewan, E., 1993. Evaporation and discharge from arable land with cropped or bare soils during winter. Measurements and simulations. Agricultural and Forest Meteorology 64: 131-159.

Novozamsky, I., R. Van Eck, J.Ch. Van Schouwenburg \& I. Walinga, 1974. Total nitrogen determination in plant material by means of the indophenol blue method. Netherlands Journal of Agricultural Science 22: 3-5.

Novozamsky, I., V.J.G. Houba, R. Van Eck \& W. Van Vark, 1983. A novel digestion technique for multi-element plant analysis. Communications in Soil Science and Plant Analysis 14: 239-249.

Penman, H.L., 1948. Natural evaporation from open water, bare soil and grass. Royal Society, London, Proceedings Series A. 193, p. 120-145.

Richter, G.M. \& J. Richter, 1991. Verlagerung und Abbau von Nitrat in der ungesättigten Zone unterhalb des Wurzelraumes. Mitteilungen der Deutschen Bodenkundlichen Gesellschaft 66: 1003-1006.

Schröder, J., W.J.M. de Groot \& W. van Dijk, 1992. Nitrogen losses from continuous maize as affected by cover crops. In: J.R. Archer, K.W.T. Goulding, S.C. Jarvis, C.M. Knott, E. Lord, S.E. Ogilvy, J. Orson, K.A. Smith \& B. Wilson (Eds.), Nitrate and farming systems, Aspects of Applied Biology 30, Association of Applied Biologists, Warwick, p. 317-326.

Schröder, J.J., W. Van Dijk, W. \& W.J.M. De Groot, 1996. Effects of cover crops on the nitrogen fluxes in a silage maize production system. Netherlands Journal of Agricultural Science 44: 293-315.

Sörensen, J.N., 1992. Effect of catch crops on the content of soil mineral nitrogen before and after winter leaching. Zeitschrift für Pflanzenernährung und Bodenkunde 155, p. 61-66.

Smit, A.L., J. Groenwold \& J. Vos, 1994. The Wageningen Rhizolab - a facility to study soil-root-atmosphere interactions in soil. II. Methods of root observations. Plant and Soil 161: 289-298.

Thorup-Kristensen, K., 1993. Root development of nitrogen catch crops and of a succeeding crop of broccoli. Acta Agriculturae Scandinavica, Sect. B, Soil and Plant Sci. 43: 58-64.

Tunney, H., 1992. The EC nitrate directive. In: J.R. Archer, K.W.T. Goulding, S.C. Jarvis, C.M. Knott, E. Lord, S.E. Ogilvy, J. Orson, K.A. Smith \& B. Wilson (Eds.), Nitrate and farming systems, Aspects of Applied Biology 30, Association of Applied Biologists, Warwick, p. 5-10.

Van Dam, A.M., J. Vos, J. Wolfert, E.A. Lantinga and P.A. Leffelaar, 1996. Growth and nitrogen accumulation of winter rye as a catch crop: model and experiment. In: M.K. Van Ittersum, G.E.G.T. Venner, S.C. Van de Geijn \& T.H. Jetten (Eds.), Book of Abstracts Fourth Congress of the European Society for Agronomy. ESA Congress Office, Wageningen, pp. 502-503.

Van Dam, A.M. \& E.A. Lantinga, 1997. Canopy $\mathrm{CO}_{2}$ assimilation in catch crops during autumn and winter. Submitted to Netherlands Journal of Agricultural Science.

Van de Geijn, S.G., J. Vos, J. Groenwold, J. Goudriaan \& P.A. Leffelaar, 1994. The Wageningen Rhizolab - a facility to study soil-root-shoot-atmosphere interactions in crops. I. Description of main functions. Plant and Soil 161: 275-287. 


\section{A.M. VAN DAM AND P.A. LEFFELAAR}

Van Noordwijk, M., 1982. Functional interpretation of root densities in the field for nutrient and water uptake. In: W. Böhm, L. Kutschera \& E. Lichtenegger (Eds.), Root ecology and its practical application. International symposium 27-29 sep. 1982, Bundesanstalt für Alpenländische Landwirtschaft, Gumpenstein, Austria, p. 207-227.

Vos, J. \& P.E.L. Van der Putten, 1997. Field observations and actual growth and nitrogen accumulation in relation to sowing and crop species. Plant and Soil 195: 299-309.

Walinga, I., W. Van Vark, V.J.G. Houba \& J.J. Van der Lee, 1989. Plant analysis procedures. Soil and plant analysis, Part 7. Wageningen Agricultural University, Dept. of Soil Science and Plant Nutrition, Wageningen.

Whitehead, D.C., 1995. Grassland nitrogen. CAB International, Oxon, 397 p.

Wyland, L. J., L.E. Jackson, W.E. Chaney, K. Klonsky, S.T. Koike \& B. Kimple, 1996. Winter cover crops in a vegetable cropping system: impacts on nitrate leaching, soil water, crop yield, pests and management costs. Agriculture, Ecosystems and Environment 59: 1-17. 